\title{
INOVASI KURIKULUM PAI TINGKAT SEKOLAH DASAR BERBASIS BUDAYA LOKAL KARO DI WILAYAH SUKU TENGGER
}

\author{
Ahmad Marzuki \& Achmad Yusuf \\ FAI Universitas Yudharta Pasuruan \\ marzuki@yudharta.ac.id \& achysf@yudharta.ac.id
}

\begin{abstract}
Abstrak:
Penelitian ini secara spesifik menginisiasi inovasi kurikulum berbasis budaya lokal di wilayah suku tengger, dengan cara memasukkan nilai-nilai budaya Karo pada kurikulum Pendidikan Agama Islam (PAI) tingkat Sekolah Dasar (SD) kelas VI. Kurikulum PAI sebagai salah satu komponen pendidikan harus dirancang dengan sebaik-baiknya agar sesuai dengan kebutuhan masyarakat. Model inovasi kurikulum PAI ini akan menentukan generasi atau masyarakat minoritas muslim di wilayah suku tengger dalam merespon pelbagai ragam budaya lokal. Pemahaman peserta didik pada materi pembelajaran PAI akan sangat menentukan eksistensi mereka di tengah-tengah masyarakat yang sangat kental dengan ritual adat dalam kehidupan sehari-hari. Ada empat bagian pada silabus, terutama pada materi pembelajaran dan kegiatan pembelajaran kelas VI pada pelajaran satu (indahnya saling menghormati), pelajaran enam (indahnya saling membantu), pelajaran delapan (senangnya berakhlak terpuji), dan pelajaran sembilan (Ayo berinfak dan bersedekah) yang akan dikembangkan dalam penelitian ini, sehimgga diharapkan pemahaman peserta didik lebih luas dan bijak dalam merespon fenomena yang terjadi di lingkungan sekitar.
\end{abstract}

Kata Kunci: Inovasi, Kurikulum PAI, Budaya, Suku Tengger

\begin{abstract}
:
This study specifically initiated local culture-based curriculum innovations in the Tengger tribal region, by incorporating karo cultural values into the class VI The Islamic Education curriculum as one component of education must be designed as well as possible to suit the needs of the community. This Islamic Education curriculum innovation model will determine the generation or minority Muslim community in the Tengger tribe region in response to various local cultures. Understanding of students in PAI learning material will greatly determine their existence in the midst of a community that is very thick with traditional rituals in daily life. There are four parts to the syllabus, especially in learning materials and learning activities of class VI in lesson one (Beautiful Respect for each other), lesson six (Beautiful Help each other), lesson eight (happy to be praiseworthy), and lesson nine (Come on and give charity) will be developed in this study, so that it is expected that the understanding of students is broader and wiser in responding to the phenomena that occur in the surrounding environment.
\end{abstract}

Keywords: Innovation, PAI Curriculum, Culture, Tengger Tribe 


\section{Pendahuluan}

Salah satu karakteristik masyarakat adat Tengger yang mayoritas beragama Hindu dalam kehidupannya cenderung mengedepankan rasa kebersamaan, kekeluargaan, rukun, mengutamakan kerja sama secara masif (kolektif) dalam menjalankan aktifitas sehari-hari. ${ }^{1}$ Masyarakat Muslim Suku Tengger di Kec. Tosari yang hanya berjumlah 6.472 jiwa, hampir separuh dari jumlah umat Hindu yang mencapai angka $11.956^{2}$ dapat berjalan secara beriringan dengan nilai-nilai budaya lokal. Misalkan rasa tali persaudaraan yang kuat, masyarakat Tengger merasa satu bersaudara meskipun berbeda agama. Mereka saling menghormati dan membantu antara satu dengan yang lainnya. Bahkan pada saat ritual selametan ${ }^{3}$ ping pitu yang merupakan salah satu rangkaian kegiatan Hari Raya Karo ${ }^{4}$, orang Islam diundang untuk makan-makan di rumahnya, dan sebaliknya jika tiba hari raya idul Fitri mereka yang beragamakan Hindu pergi untuk makan-makan/silaturahmi di rumah orang Islam. ${ }^{5}$ Demikianlah mereka dalam hal persaudaraan bisa dikatakan saling menghormati.

Teori W. Robertson Smith tentang upacara bersaji menyatakan bahwa upacara religi atau agama, yang biasanya dilakukan oleh banyak warga masyarakat pemeluk religi atau agama yang bersangkutan bersama-sama mempunyai fungsi sosial untuk mengintensifkan solidaritas masyarakat. Motivasi mereka tidak mengutamakan untuk berbakti kepada Tuhannya, atau untuk mengalami kepuasan keagamaan secara pribadi, tetapi juga karena mereka menganggap bahwa melakukan upacara adalah suatu kewajiban sosial. ${ }^{6}$

Beragamnya upacara adat yang berkembang di wilayah Tengger terkadang akan menimbulkan 'kegagapan' bagi masyarakat muslim yang hidup di daerah ini; Apakah tradisi-tradisi ini membawa kepada kesyirikan karena menyajikan sesajen pada roh para leluhur yang artinya mempercayai adanya kekuasaan selain Allah. Selain itu juga pada pelaksanaanya lebih banyak menggunakan unsur budaya Hindu Mahayana. Maka disinilah umat Islam diharuskan bersikap selektif dan berpengetahuan luas.

\footnotetext{
${ }^{1}$ Ayu Sutarto, Sekilas Tentang Masyarakat Suku Tengger, Makalah disampaikan pada acara pembekalan Jelajah Budaya 2006 yang diselenggarakan oleh Balai Kajian Sejarah dan Nilai Tradisional Yogyakarta, tanggal 7-10 Agustus 2006, 1.

${ }^{2}$ Kabupaten Pasuruan Dalam Angka 2014. Badan Pusat Statistik Kabupaten Pasuruan, 213.

${ }^{3}$ Selametan adalah ritual muslim jawa yang dilakukan untuk mendapatkan berkah tertentu dari tuhan. Lihat Hilmy, Masdar, Islam and Javanese Acculturation: Textual and Contextual Analysis of The Slametan Ritual, (Canada: McGill University Montreal, 1999), 41.

${ }^{4}$ Karo merupakan salah satu upacara adat suku Tengger yang dilaksanakan pada bulan kedua berdasarkan kalender saka. Salah satu ritualnya adalah masyarakat dari berbagai latar belakang agama apapun melakukan anjangsana ke sanak saudara dan tetangga selama tujuh hari. Lebih dari itu, Karo memiliki pesan kultural yang menganjurkan persatuan dan kesatuan dalam perbedaan iman antara Budha-Hindu dan Islam. Lihat Ayu Sutarto, Sastra Lisan Tengger Pilar Utama Pemertahanan Tradisi Tengger, Jurnal ATAVISME, Volume 12, No. 1, Edisi Juni 2009: 9-21

${ }^{5}$ Anis, Wawancara Pribadi, Desa Ngadiwono Kec. Tosari Kab. Pasuruan, 17 April 2014.

${ }^{6}$ Koentjaraningrat, Sejarah Teori Antropologi I, (Jakarta: UI-PRESS, 1987), 67-68.
} 
Memahami universalitas ajaran Islam $^{7}$ tentu saja dibutuhkan lembaga pendidikan yang mampu berperan aktif dan inovatif dalam mentransmisikan nilainilai Islam secara komprehensif kepada masyarakat muslim Tengger. Eksistensi Sekolah Dasar (SD) ${ }^{8}$ sebagai salah satu pranata pendidikan yang mengajarkan mata pelajaran Pendidikan Agama Islam (PAI) memiliki peran penting dalam rangka proses sosialisasi dan atau enkulturasi untuk mengantarkan peserta didik muslim Tengger ke dalam kehidupan bermasyarakat yang berbudaya, serta untuk menjaga kelangsungan eksistensi masyarakat dan kebudayaanya.

Penelitian ini secara spesifik menginisiasi inovasi kurikulum berbasis budaya lokal dengan cara memasukkan nilai kearifan lokal Karo pada kurikulum PAI tingkat SD. Sebagaimana menurut Nasution kurikulum itu harus memiliki relevansi dengan kebutuhan masyarakat. ${ }^{9}$ Oleh karenanya diperlukan kurikulum sekolah yang dapat menjawab kebutuhan masyarakat baik saat ini maupun yang akan datang. Kemampuan sekolah dalam mendesain kurikulum yang berorientasi kepada masyarakat itu harus mempertimbangkan peserta didik sebagai bagian dari anggota masyarakat, peserta didik harus dididik sesuai dengan keadaan masyarakat, karena dia akan kembali kepada masyarakat setelah mereka selesai menempuh studi mereka di sekolah. Jika ditemukan lulusan sekolah yang tidak dapat menjadi anggota masyarakat yang baik dan berguna, menjadi beban masyarakat, maka sudah tentu tujuan pendidikan itu gagal.

Kurikulum PAI sebagai salah satu komponen pendidikan harus dirancang dengan sebaik-baiknya agar sesuai dengan kebutuhan masyarakat. Oleh karenanya berbagai inovasi kurikulum PAI diperlukan untuk menemukan sebuah bentuk atau model yang sesuai dengan masing-masing kondisi daerah atau negara tertentu. Model inovasi kurikulum PAI ini akan menentukan generasi atau masyarakat seperti apa yang dibutuhkan dan dikehendaki oleh masyarakat pada masa yang akan datang dan bagaimana mewujudkan masyarakat yang dicita-citakan itu.

Lebih dari itu, PAI menjadi spirit dan inspirasi bagi mata pelajaran lain dalam menumbuhkan karakter dan watak anak didik. Selain itu, PAI juga bertujuan agar peserta didik menjadi anak yang berkepribadian (akhlak mulia). Posisi strategis PAI belum sepenuhnya terealisasi. Hal itu tampak pada beberapa kelemahan PAI. Pertama, dalam realitas di lapangan, materi Pendidikan Agama Islam belum banyak menyentuh problem aktual yangdihadapianak. Selain itu, belum sesuai dengan perkembanganbio-psikologis anak. Materi ajar PAI cenderung normatif, belum kontekstual. ${ }^{10}$ Pendidikan Agama Islam masih berpusat pada berbagai hal

\footnotetext{
${ }^{7}$ Memahami universalitas ajaran Islam yang dimaksud adalah dengan menempatkan ayat suci alQuran secara proporsional bukan dalam perspektif ilmiah teoretik, melainkan sebagai sebuah kitab inspirasi bagi umat Muslim dalam pencarian ilmiah yang tiada henti. Lihat, Masdar Hilmy, "Induktivisme Sebagai Basis Pengembangan Ilmu Pengetahuan Dalam Islam", Jurnal Studi Keislaman Volume 17 Nomor 1 (Juni) 2013, 102-103.

${ }^{8}$ Jumlah Sekolah Dasar yang tersebar di wilayah suku tengger sabrang kulon (Kecamatan Tosar) 16 sekolah. Dari total 16 sekolah, diperkirakan terdapat empat sekolah yang memiliki siswa beragama Islam lumayan banyak (hampir separuh dari jumlah total siswa). Diantaranya, SDN Tosari I, SDN Tosari II, SDN Mororejo I, dan SDN Mororejo II. Lihat http://dapo.dikdasmen.kemdikbud.go.id/sp/3/051904. diakses pada tanggal 30 Agustus 2018.

${ }^{9}$ S. Nasution, Sosiologi Pendidikan. Edisi 2, cetakan 4(Jakarta: Bumi Aksara,2009), 148 ${ }^{10}$ Turhan Yani, Sistematika dan Relevansi Materi Ajar PAI dalam Kurikulum Berbasis Kompetensi (Surabaya: Lemlit Unesa, 2007), 1.
} 
yang bersifat simbolik, ritualistik, serta bersifat legal-formalistik (halal-haram). Sehingga, ia kehilangan ruh etikanya. ${ }^{11}$

Kedua, pembelajaran Pendidikan Agama Islam masih menggunakan metode yang kurang variatif dan cenderung tradisional. Pembelajaran PAI belum memanfaatkan beberapa penemuan baru dibidang pembelajaran. Ketiga, kegiatan pendidikan agama cenderung memompakan materi ajar pada ranah kognitif, dan tidak sampai pada penghayatan dan pengamalan dalam kehidupan sehari-hari. ${ }^{12}$

Merujuk pada potensi kearifan lokal suku Tengger sebagai modal sosial-kultur, menyimpan pengalaman, sejarah, jejak-jejak kreativitas dan capaian peradaban dan pengetahuan, namun disisi lain dikhawatirkan terjebak pada perilaku bid'ah dan syirik saat melestarikannya. Maka dimungkinkan menginisiasi inovasi kurikulumPAI Tingkat SD berbasis budaya lokal suku tengger dengan cara menggali kearifan lokal tradisi karo sebagai bahan kajian awal untuk diintegrasikan dengan kurikulum mata pelajaran PAI tingkat SD di wilayah suku Tengger.Dengan mengintegrasikan Budaya lokal Karo dalam kurikulum PAI ini diharapkan dapatmembentuk karakter dan watak peserta didiklebih bijak dalam menanggapi permasalahan budaya,sosial, dan keagamaan masyarakat suku Tengger.

Dengan demikian, uraian yang telah dikemukakan di atas, signifikansi penelitian ini adalah mentransmisikan nilai dan ritual budaya karo sesuai visi dan misi Pendidikan Agama Islam tingkat SD. Menurut peneliti, hal ini penting dikaji karena sebagai bagian dari tanggung jawab moral dan kepedulian dalam melestarikan budaya lokal sebagai identitas bangsa.

\section{Metode \\ Penelitian}

Penelitian ini merupakan penelitian pengembangan (Developmental Research). ${ }^{13}$ Penelitian pengembangan berorientasi pada pengembangan suatu produk yang proses pengembangannya dideskripsikan secara detail dan produknya dievaluasi. ${ }^{14}$ Produk yang dikehendaki dalam penelitian ini adalah prototype perangkat pembelajaran mata pelajaran PAI berbasis budaya karo bagi siswa SD di wilayah suku tengger. Untuk merealisasikan prototype tersebut, pembahasan difokuskan pada dua hal, yaitu: (1) pengembangan perangkat pembelajaran PAI yang terintegrasi dengan nilai-nilai budaya lokal karo dan (2) pengembangan instrumen.

\footnotetext{
11 Muhaimin, Arah Baru Pengembangan Pendidikan Islam (Yogyakarta: Nuansa, 2003), 183.

12 Nursisto, Membumikan Pembelajaran Agama Islam (Yogyakarta: Adi Cita Karya Nusa, 2008), 23. Lebih lanjut Nursisto mengkritisi pembelajaran Agama Islam yang memiliki beberapa kekurangan yaitu: kognitif centris, teoritis, guru kurang kreatif, dan keterpencilan pembelajaran PAI dibanding mata pelajaran yang lain. Ibid., 18.

13 Terdapat beberapa model pengembangan pendidikan yaitu model Borg and Gall dengan sepuluh fase pengembangan, Four D Model, dan model pengembangan Dick and Carey. Dick and Carey, The Systematic Design of Instruction (Florida: Harper Collens Publisher, 1990), 2.

${ }^{14}$ Nana Syaodah Sukmadinata, Metode Penelitian Pendidikan (Bandung: Rosda Karya, 2009), 168.
} 


\section{Pembahasan dan Hasil Penelitian}

\section{Inovasi Kurikulum dan Pembelajaran PAI di Sekolah Dasar}

Kurikulum adalah seperangkat rencana dan pengaturan mengenai tujuan, isi danbahan pelajaran serta cara yang digunakan sebagai pedoman penyelenggaraan kegiatan pembelajaran untuk mencapai tujuan pendidikan tertentu. Kurikulum adalah suatu hal yang esensial dalam suatu penyelenggaraan pendidikan. Secara sederhana, kurikulum dapat dimengerti sebagai suatu kumpulan atau daftar pelajaran yang akan diajarkan kepada peserta didik komplit dengan cara pemberian nilai pencapaian belajar dikurun waktu tertentu.

Pembelajaran yang merupakan serangkaian kegiatan yang dirancang untuk memungkinkan terjadinya proses belajar pada siswa. Implikasinya bahwa pembelajaran sebagai suatu proses harus dirancang, dikembangkan dan dikelola secara kreatif, dinamis, dengan menerapkan pendekatan multi untuk menciptakan suasana dan proses pembelajaran yang kondusif bagi siswa.

Pembelajaran sebagai suatu sistem atau proses membelajarkan siswa yang direncanakan, dilaksanakan, dan dievaluasi secara sistematis agar pembelajar dapat mencapai tujuan pembelajaran secara aktif, efektif, dan inovatif. Pembelajaran merupakan sesuatu yang kompleks, artinya segala sesuatu yang terjadi pada proses pembelajaran harus merupakan sesuatu yang sangat berarti baik ucapan, pikiran maupun tindakan.

Inovasi kurikulum dan pembelajaran adalah suatu ide, gagasan atau tindakantindakan tertentu dalam bidang kurikulum dan pembelajaran yang dianggap baru untuk memecahkan masalah-masalah pendidikan. Inovasi biasanya muncul dari keresahan pihak-pihak tertentu tentang penyelenggaraan pendidikan, dengan kata lain bahwa inovasi itu ada karena adanya masalah yang dirasakan. ${ }^{15}$

Inovasi memilki beberapa sifat perubahan yaitu:

a. Penggantian (substitution), inovasi dalam penggantian jenis sekolah, penggantian bentuk perabot, alat-alat atau system ujian yang lama diganti dengan yang baru.

b. Perubahan (alternation), merubah tugas guru yang tadinya hanya bertugas mengajar, juga harus bertugas menjadi guru pembimbing. Perubahan yang bersifat sebagian komponen dari sekian banyak komponen yang masih dapat dipertahankan dalam sistem lama.

c. Penambahan (addition), inovasi yang besifat penambahan tidak ada penggantian atau perubahan. Kalaupun ada yang berubah, maka perubahan tersebut hanya dalam lingkup komponen dalam system yang masih dipertahankan.

d. Penyusunan kembali (restructuring). Upaya penyusunan kembali berbagai komponen yang telah ada dalam system dengan maksud agar mampu menyesuaikan diri dengan tuntutan dan kebutuhan.

e. Penghapusan (elimination). Upaya perubahan dengan cara menghilangkan aspek-aspek tertentu dalam pendidikan atau pengurangan komponenkomponen tertentu dalam pendidikan atau penghapusan pola atau cara-cara lama.

15 Wina Sanjaya, Inovasi Kurikulum dan Pembelajaran: Teori dan Praktik Pengembangan Kurikulum TingkatSatuan Pendidikan (KTSP), (Jakarta: Kencana Prenada Media Group, 2010), 318 
f. Penguatan (reinforcement). Upaya peningkatan untuk memperkokoh atau memantapkan kemampuan atau pola dan cara-cara yang sebelumnya terasa lemah.

Pengembangan kurikulum adalah suatu proses yang menentukan bagaimana pembuatan kurikulum yang akan berjalan. Agar pengembangan kurikulum dapat berhasil sesuai dengan yang diinginkan, maka di dalam pengembangan kurikulum diperlukan.

Landasan-landasan pengembangan kurikulum yaitu:(1) Landasan Filosofis, (2)Landasan Sosial-Budaya-Agama, (3) Landasan Ilmu Pengetahuan Teknologi dan Seni, (4) Landasan Kebutuhan Masyarakat, (5) Landasan Perkembangan Masyarakat. ${ }^{16}$

Beberapa faktor yang menuntut adanya inovasi kurikulum dan pembelajaran adalah sebagai berikut:

a. Perkembangan ilmu pengetahuan menghasilkan kemajuan teknologi yang mempengaruhi kehidupan sosial, ekonomi, politik, pendidikan, dan kebudayaan bangsa Indonesia.

b. Laju eksplosi penduduk yang cukup pesat, yang menyebabkan daya tampung, ruang, dan fasilitas pendidikan yang sangat tidak seimbang.

c. Melonjaknya aspirasi masyarakat untuk memperoleh pendidikan yang lebih baik, sedangkan dipihak lain kesempatan sangat terbatas.

d. Mutu pendidikan yang dirasakan makin menurun, yang belum mampu mengikuti perkembangan ilmu pengetahuan dan teknologi.

e. Belum berkembangnya alat organisasi yang efektif, serta belum tumbuhnya suasana yang subur dalam masyarakat untuk mengadakan perubahan perubahan yang dituntut oleh keadaan sekarang dan yang akan datang.

f. Kurang ada relevansi antara program pendidikan dan kebutuhan masyarakat yang sedang membangun.

g. Keterbatasan dana.

Prinsip-prinsip yang berlaku dan dapat kita pakai sebagai dasar dalam upaya pembelajaran, baik bagi siswa yang perlu meningkatkan upaya belajarnya maupun bagi guru dalam upaya meningkatkan cara mengajarnya, prinsip-prinsip tersebut adalah: (1) Perhatian dan motivasi, (2) Keaktifan, (3) Keterlibatan langsung, (4) Pengulangan, (5) Tantangan, (6) Balikan dan penguatan, (7) Perbedaan individual. ${ }^{17}$

Pembuatan keputusan dalam pembinaan kurikulum bukan saja menjadi tanggung jawab para perencana kurikulum, akan tetapi juga menjadi tanggung jawab para guru di sekolah. Para perencana kurikulum perlu membuat keputusan yang tepat, rasional, dan sistematis. Pembuatan keputusan itu tidak dapat dibuat secara acak-acakan, melainkan harus berdasarkan informasi dan data yang obyektif. ${ }^{18}$

Kurikulum meliputi komponen-komponen, yaitu tujuan pendidikan, tujuan instruksional, alat dan metode instruksional, pemilihan dan pembimbingan materi

\footnotetext{
${ }^{16}$ Dimyati \& Mudjiono, Belajar dan Pembelajaran, (Jakarta: PT. Rineka Cipta, 2002), 268

17 Dimyati \& Mudjiono, Belajar dan Pembelajaran................, 42.

${ }^{18}$ Oemar Hamalik, Pendidikan Guru: Berdasarkan Pendekatan Kompetensi, (Jakarta: PT. Bumi Aksara, 2002), 20.
} 
program, evaluasi dan staf pelaksanaan kurikulum. Semua komponen tersebut harus dipertimbangkan dalam penyusunan kurikulum secara keseluruhan. ${ }^{19}$

Beberapa kriteria dan syarat dalam inovasi kurikulum: (1) Kurikulum harus up to date, (2) Kurikulum memberikan kemudahan untuk memahami prinsipprinsip pokok dan generalisasi-generalisasi, (3) Kurikulum memberikan kontribusi pengembangan keterampilan, kebiasaan berfikir bebas, dan disiplin berdasarkan pengetahuan, (4) Kurikulum menyumbang terhadap pengembangan moralitas yang esensial dan yang berkenaan dengan evaluasi dan penggunaan pengetahuan, (5) Kurikulum mempunyai makna dan maksud bagi para siswa, (6) Kurikulum menyediakan suatu ukuran keberhasilan dan suatu tantangan, (7) Kurikulum menyumbang terhadap pertumbuhan yang seimbang, (8) Kurikulum mengarahkan tindakan sehari-hari dan mengarahkan pelajaran serta pengalaman selanjutnya. ${ }^{20}$

\section{Nilai Kearifan Budaya Lokal}

Nilai adalah sesuatu yang berharga, sehingga menjadi patokan dalam kehidupan. Nilai memberi makna dalam hidup, sehingga memberi corak dalam perilaku manusia. ${ }^{21}$ William mengemukakan sebagaimana dikutip Armiah, bahwa nilai merupakan "...What is desirable, good or bad beautiful or ugly". Sedang Light, Keller \& Colhoun memberikan batasan nilai sebagai berikut: "Value is general idea that people share about what is good or bad, desirable or undesirable. Value transcend any one particular situation... Value people hold tend to color their overall way of life". 22

Diantara nilai tersebut, kearifan lokal adalah budaya masyarakat yang telah diciptakan oleh nenek moyang dan menjadi warisan bagi anak cucunya dan sebagai alat kontrol tingkah laku masyarakat. Nilai-nilai yang dianggap sebagai alat kontrol sosial dianggap juga sebagai nilai agama yang menjadi pedoman bagi kehidupan manusia. Sedangkan nilai yang tidak sesuai dengan nilai keagamaan dianggap oleh masyarakat sebagai yang tidak bisa menghargai nilai. Nilai yang dijadikan patokan dari kearifan lokal di masyarakat, telah lama berevolusi dalam masyarakat maupun lingkungan dan sudah beberapa kali mengalami masa periode generasi ke generasi. ${ }^{23}$

Dengan adanya perubahan sosial di masyarakat, mengakibatkan kearifan lokal, hampir terlupakan oleh masyarakat saat ini dan hampir juga terlupakan oleh sejarah dalam kehadirannya. Zaman nenek moyang, kearifan lokal terbentuk oleh adat dan tradisi masyarakat, sehingga dapat dikatakan sebagai produk budaya. Zaman sekarang, kearifan lokal sudah hampir tidak dikenali oleh masyarakat bahkan dunia pendidikan saat ini, disebabkan oleh kearifan lokal telah tergantikan oleh pendidikan karakter. Jika dilihat dari sejarah kearifan lokal, pendidikan

19 Oemar Hamalik, Pendidikan Guru: Berdasarkan ..................., 22.

20 Oemar Hamalik, Pendidikan Guru: Berdasarkan ...................., 70.

${ }^{21}$ Nashihin, "Internalisasi Nilai-Nilai Agama Islam dalam Pembinaan Akhlak Mulia," Jurnal Ummul Qura, Vol. 5, No. 1, 2015, 2.

22 Armiah, "Internalisasi Nilai-Nilai Keagamaan Lewat Media," Alhadharah, Vol.13, No. 25, 2014, 2

23 Hasbullah, "Rewang: Kearifan Lokal dalam Membangun Solidaritas dan Integrasi Sosial Masyarakat di Desa Bukit Batu Kabupaten Bengkalis, "Jurnal Sosial Budaya, Vol. 9, No. 2, 2012, 231 232. 
karakter hampir sama maknanya dengan kearifan lokal. Karena, kearifan lokal kurang diperhatikan oleh dunia pendidikan kita, sehingga pendidikan karakter hadir dalam dunia pendidikan yang juga terdiri dari nilai. Jika dikaji lebih mendalam, bahwa pendidikan karakter adalah pendidikan yang mengajarkan nilainilai positif, agar nilai tersebut menjadi kepribadian dalam diri anak. Sedangkan kearifan lokal adalah warisan leluhur nenek moyang yang mengajarkan nilai-nilai positif juga, untuk diturunkan ke generasi ke generasi agar nilai tersebut dapat menjadi alat kontrol dalam dirinya. Untuk lebih jelasnya, coba kita perhatikan tentang pengertian kearifan lokal itu sendiri.

Secara etimologi "kearifan (wisdom) berarti kemampuan seseorang dalam menggunakan akal pikirannya untuk menyikapi suatu kejadian, obyek, atau situasi". Sedangkan lokal berarti kejadian yang terjadi pada daerahnya. Kearifan lokal adalah pikiran positif manusia yang berhubungan dengan alam, lingkungan yang bersumber dari adat istiadat, nilai agama, petuah-petitih nenek moyang yang terbentuk oleh masyarakat sekitar. Warisan ini dijadikan sebagai alat kontrol di masyarakat dan sudah melembaga sehingga menjadi kebudayaan. ${ }^{24}$

\section{Upacara Karo, Ritual Adat Mengandung Nilai Kearifan Lokal}

Tengger sering hanya dikenal dengan upacara Kasodo dan Gunung Bromonya. Padahal ada pula upacara Karo yang tak kalah penting bagi masyarakat Tengger. Tak main-main, perhelatan tradisional itu berlangsung hingga 15 hari. Upacara Karo merupakan upacara yang dilakukan oleh masyarakat suku Tengger untuk memuliakan tradisi leluhur. Selain sebagai tradisi upacara ini juga merupakan selametan ${ }^{25}$ masyarakat suku Tengger terhadap para leluhur. ${ }^{26}$ Upacara Karo dilaksanakan pada bulan kedua menurut kalender orang Tengger itu dimaksudkan untuk memanjatkan puji syukur kepada Sang Pencipta atas berkah-Nya sepanjang tahun. Ritual yang juga mereka sebut riyaya (merayakan hari raya keagamaan) itu pun layaknya hari raya lainnya, upacara Karo disambut dengan suka cita. Warga masyarakat saling mengunjungi, sambil tak lupa mengenakan baju baru dan menyediakan makanan yang berlimpah.

Berbagai ritual untuk menyambut hari raya karo, diantaranya tarian remo dan alunan gending kemudian, warga desa berhamburan, saling desak dan dorong mendekati sebuah tumpeng besar. Sesaat alunan gending digantikan oleh suara celoteh, tawa, teriakan bersahutan saat berebut tumpeng besar itu, yang mereka sebut Tumpeng Gede. Itulah gambaran sekilas salah satu bagian dari ritual Karo yang dilakukan masyarakat Tengger Bersumber dari hasil wawancara dengan Bapak Sunyoto, salah satu tokoh masyarakat Tengger dari

\footnotetext{
24 Imam Santoso Ermawi, Kearifan Lokal Dalam Perencanaan dan Perancangan Kota Untuk Mewujudkan Arsitektur Kota Yang Berkelanjutan (Malang: Group Konservasi Arsitektur dan Kota, Universitas Merdeka Malang, 2009), 7.

${ }^{25}$ Secara bahasa kata slametan berasal dari bahasa Jawa yang berasal dari kata dasar selamet yang berarti selamat. Sedangkan menurut istilah selametan adalah menciptakan keadaan sejahtera, aman, bebas dari gangguan makhluk halus. Lihat Andrew Beatty, Varian Agama di Jawa: Suatu Pendekatan Antropologi, terj. Achmad Fedyani Saifuddin (Jakarta: Raja Grafindo Persada, 1999), 43. 26 Pak Jono, Ceritane Karo Ceritane Kasodo, 2005, 8.
} 
desa Ngadiwono mengenai upacara Karo, berikut ini adalah rangkaian upacara Karo yang dilakukan selama 15 hari:

a. Selamatan ping pitu (selamatan tujuh kali tujuh hari). Upacara ini bertujuan mengundang roh leluhur setiap keluarga ke rumah masing-masing. Arwah yang datang itu lalu dijamu makanan dan minuman. Roh leluhur itu diundang agar mau merestui dan mem-berkati kehidupan rumah tangga mereka. Selama roh leluhur"berada di rumah, mereka berusaha menyenangkannya. Pantang bagi mereka untuk membuat arwah-arwah itu murka.

b. Prepekan Karo. Acara itu dimeriahkan dengan tari tari Sodoran yang dimainkan pria.

c. Penari menari untuk menghormati arwah di beberapa tempat yang di anggap penting dan keramat. Tempat tersebut misalnya pedhayangan (tempat roh penjaga desa), punden desa (makam leluhur desa), sumber air (sumber air diyakini dijaga oleh roh). Upacara ini ditujukan agar tidak kualat karena arwah leluhur dilangkahi

d. Warga berkunjung ke rumah kepala desa. Upacara ini dilakukan pada pukul 19.00. Kegiatan berkunjung ini dilakukan oleh para tetua adat, tokoh masyarakat dan pamong desa.

e. Keesokan harinya warga berkunjung ke rumah kepala desa sambil membawa tumpeng yang akan disandingkan dengan tumpeng gede

f. Dukun melafalkan mantra yang ditujukan untuk tumpeng

g. Warga berebut tumpeng gede. Potongan tumpeng dijadikan sebagai oleholeh yang wajib dibawa pulang agar tidak kualat.

h. Dukun dan pembantunya mempersiapkan acara nundung roh "memulangkan roh"

i. Dukun melakukan perjalanan keliling desa mengunjungi setiap warga desa dengan membawa prapen (tungku api) dan air suci.

j. Pada hari ke-15 atau sebagai penutup diadakan sadranan. Upacara ini dimaksudkan untuk mendoakan arwah leluhur dan keluarganya yang sudah meninggal.

\section{Inovasi Kurikulum PAI Berbasis Budaya Lokal Karo}

Upaya inovasi kurikulum PAI sesungguhnya sebagai solusi atas problem yang dihadapai masyarakat, terutama siswa SD beragama Islam sebagai kelompok minoritas yang bermukim di wilayah suku Tengger. Problem yang dimaksud adalah tentang bagaimana 'kegagapan' peserta didik ketika dihadapkan dengan berbagai ritual adat diantaranya upacara karo yang begitu kental dan mengakar kuat di lingkungan masyarakat yang dihuni mayoritas penduduk beragama Hindu.

Berbagai ritual adat yang begitu kental merupakan bagian dari konstruksi budaya dan proses interaksi sosial yang tak bisa terhindarkan bagi masyarakat, maka sudah semestinya kegiatan pembelajaran PAI menjadi solusi untuk membekali peserta didik agar lebih arif dalam menyikapinya. Bukan sebaliknya, pembelajaran PAI justru semakin mengasingkan peserta didik dengan apa yang terjadi di lingkungan sekitar. Inilah yang kemudian menjadi landasan filosofis dan landasan sosial-budaya perlunya inovasi kurikulum PAI berbasis budaya lokal. Ada 
6 komponen perubahan dalam Inovasi menurut Huberman, yaitu:27 (1) Penggantian (Substitution), penggantian jenis sekolah, penggantian bentuk perabot, alat-alat atau sistem ujian yang lama diganti dengan yang baru. (2) Perubahan (Alternation), upaya mengubah tugas guru yang awalnya hanya bertugas mengajar, juga harus bertugas menjadi guru bimbingan dan penyuluhan. (3) Penambahan (Addition) yaitu Inovasi yang bersifat penambahan terhadap komponen yang terdapat dalam sistem yang masih perlu dipertahankan. (4) Penyusunan kembali (Restructuring), Upaya penyusunan kembali berbagai komponen yang ada dalam sistem dengan maksud agar mampu menyesuaikan diri dengan tuntutan dan kebutuhan. (5) Penghapusan (Elimination) yaitu upaya pembaruan dengan cara menghilangkan aspek-aspek tertentu dalam pendidikan atau pengurangan komponen-komponen tertentu dalam pendidikan atau penghapusan pola atau cara-cara lama. Seperti menghapus mata pelajaran tertentu seperti mata pelajaran menulis halus, dan (6) Penguatan (Reinforcement) yaitu upaya peningkatan untuk memperkokoh atau memantapkan kemampuan atau pola dan cara-cara yang sebelumnya terasa lemah.

Setidaknya ada dua sifat inovasi yang akan diterapkan pada kurikulum PAI dalam konteks penelitian ini. Pertama, penambahan (addition), inovasi yang besifat penambahan. Kedua, Penguatan (reinforcement). Upaya peningkatan untuk memperkokoh atau memantapkan kemampuan atau pola dan cara-cara yang sebelumnya terasa lemah.

Upaya penambahan dan penguatan yang dimaksud pada silabus, terutama pada materi pembelajaran dan kegiatan pembelajaran kelas VI pada pelajaran satu (Indahnya Saling Menghormati), pelajaran enam (Indahnya Saling Membantu), pelajaran delapan (senangnya berakhlak terpuji), dan pelajaran sembilan (Ayo berinfak dan bersedekah). Setelah silabus dikembangkan, maka selanjutnya mengembangkan Rencana Pelaksanaan Pembelajaran. Proses ini merupakan bagian dari upaya meningkatkan kualitas pembelajaran langsung, dimana peserta didik mengembangkan pengetahuan, kemampuan berpikir dan keterampilan psikomotorik melalui interaksi langsung dengan sumber belajar yang dirancang dalam silabus dan RPP berupa kegiatan-kegiatan pembelajaran sesuai dengan kondisi masyarakat suku tengger.

Dalam prosesnya, ada beberapa tahapan saat menginisiasi inovasi kurikulum PAI tingkat SD berbasis budaya lokal, pertama, mengkaji kompetensi inti dan kompetensi dasar. Kompetensi inti adalah tingkat kemampuan untuk mencapai standart kopetensi lulusan yang harus dimiliki oleh peserta didik pada setiap tingkat, kelas atau program. Sedangkan kompetensi dasar adalah kemampuan untuk mencapai kompetensi inti yang harus diperoleh peserta didik melalui pengalaman pembelajaran. ${ }^{28}$

Pada pelajaran bab satu buku PAI kelas VI tingkat SD kurikulum 2013 terdapat kompetensi dasar "Menunjukkan perilaku toleran, simpati, waspada, berbaik

\footnotetext{
27 Huberman, AM. Understanding Change in Education. (New York. IBE; 1973). 11-12.

28 Peraturan Menteri Pendidikan Dan Kebudayaan Republik Indonesia Nomor 24 Tahun 2016 tentang Kompetensi Inti Dan Kompetensi Dasar Pelajaran pada Kurikulum 2013 Pada Pendidikan Dasar Dan Pendidikan Menengah, 3-4.
} 
sangka dan hidup rukun ${ }^{29}$ sebagai implementasi dari pemahaman Q.S. al-Kafirun, Q.S. al-Ma'idah/5:2-3 dan Q.S. al-Hujurat/49:12-13". 30 Maka dimungkinkan ada ruang untuk diinovasi dengan cara menarasikan KD tersebut lebih operasional dan implementatif sesuai dengan kondisi masyarakat suku Tengger. Karena peserta didik sangat membutuhkan kepastian hukum saat mereka berinteraksi dengan ragam budaya lokal yang Ia hadapi hampir setiap hari. Perilaku toleran dapat ditunjukkan dengan cara menghormati dan menghargai berbagai rangkaian acara upacara karo. Semisal ada ritual santi, yakni dukun membaca mantra atau mendoakan dengan cara mendatangi tiap rumah penduduk. Maka sikap yang harus dtunjukkan adalah dengan cara menghormati (tidak menjelekkan) apa yang mereka lakukan dan tentu saja bukan berarti meyakini apa yang mereka jalankan (waspada).

Namun di sisi lain peserta didik juga diajarkan tentang sikap simpati terhadap berbagai rangkain acara adat yang memang di dalamnya tidak berpotensi merusak aqidah Islam. Karena jika ditelusuri lebih dalam justru sebaliknya, ada beberapa ritual adat mengandung nilai-nilai kearifan lokal dan itu sejalan dengan ajaran Islam. Semisal acara anjang sana-anjang sini selama tujuh hari saat merayakan hai raya karo. Kegiatan ini lebih dominan pada motivasi sosial masyarakat suku tengger untuk meningkatkan tali persaudaraan dan kerukunan antar warga melewati sekat-sekat kepercayaan, agama dan suku tertentu. Sebagai warga tengger mereka yang beragama Hindu, Islam, Kristen semuanya terlibat dalam kegiatan ini.

Kedua, mengidentifikasi materi/pokok pembelajaran pada pelajaran enam "Indahnya Saling Membantu". Sebagaimana termuat dalam silabus, berikut materi pembelajaran pelajaran keenam;

a. Membaca Al Qur'an hendaknya dimulai dengan isti'azah dan basmalah.

b. Bunyi QS Al Maidah ayat 2: "wata'aawanuu 'alalbirri wattaqwaa, wa laa ta'aawanuu 'alal itsmi wal 'udwaan". Artinya: Dan tolong menolonglah kamu dalam mengerjakan kebajikan dan taqwa, dan jangan tolong menolong dalam berbuat dosa dan permusuhan.

c. Kandungan QS Al Maidah ayat 2:

$\checkmark$ Dianjurkan untuk saling tolong menolong dalam kebaikan dan taqwa

$\checkmark$ Diprintahkan untuk menghindari tolong menolong dalam kejahatan.

Ketiga, mengembangkan kegiatan pembelajaran, terutama pada tahapan kegiatan inti dengan cara mendiskusikan materi pembelajaran dan berusaha mengkaitkan dengan berbagai ritual adat suku tengger terutama rangkaian kegatan upacara karo. Semisal pada pelajaran akhlak terpuji. Ada pembahasan tentang kandungan surat al-Hujurat ayat 12. Berikut instruksi saat kegiatan inti pembelajaran

a. Perhatikan Cerita sejarah Hari Raya Karo

b. Guru meminta peserta didik secara berkelompok mencermati alur cerita dan ulasan tentang berpikir positif serta gambar/ilustrasi sebagaimana terdapat dalam bahan ajar yang telah dikembangkan.

${ }^{29}$ Kementerian Pendidikan dan Kebudayaan. Buku Guru Pendidikan Agama Islam dan Budi Pekerti. (Jakarta: Kementerian Pendidikan dan Kebudayaan, 2015),71.

${ }^{30}$ Aplikasi MS. Quran In Word Kemenag, Lajnah Pentashih Mushaf al-Quran Kemenag. V.2.2. 2013. QS. 49:12-13. 
c. Selanjutnya, setiap kelompok mendiskusikan makna yang terkandung dalam cerita dan gambar/ilustrasi serta keterkaitannya dengan ulasan tentang berpikir positif.

d. Setiap kelompok menyampaikan hasil diskusinya dan kelompok lain ikut mencermati dan mengemukakan pertanyaan-pertanyaan yang relevan.

e. Guru memberikan penguatan terhadap hasil diskusi peserta didik, kemudian menjelaskan maksud cerita dan keterkaitannya dengan berpikir positif (berbaik sangka) berdasarkan bahanajaryang telah dikembangkan atau sumber lain yang relevan.

f. Arti Berbaik Sangka

Berbaik sangka Secara bahasa berasal dari bahasa Arab yaitu husnuzzan berasal dari dua kata, yaitu husnu dan zan yang artinya berbaik sangka. Secara istilah, husnuzzan diartikan berbaik sangka terhadap segala ketentuan dan ketetapan Allah yang diberikan kepada manusia. ${ }^{31}$ Husnuzzan merupakan salah satu bagian dari akhlak terpuji. ${ }^{32}$ Lawan dari husnuzzan adalah su'uzzan yang artinya jahat sangka. Su'uzzan atau berburuk sangka adalah perbuatan yang tidak diperbolehkan karena dapat mengakibatkan permusuhan dan retaknya persaudaraan ${ }^{33}$

g. Peserta didik secara berkelompok kembali mengkaji dan mendiskusikan arti berbaik sangka yang terkandung dalam Q.S. al-Hujurat/49:12. Berdasarkan hasil kajian tersebut, setiap kelompok merumuskan beberapa pertanyaan untuk dikemukakan pada kelompok lain.

h. Setiap kelompok menyampaikan hasil diskusinya, sementara kelompok lain ikut serta mencermati dan mengemukakan beberapa pertanyaan yang relevan yang telah dipersiapkan bersama kelompok. Guru memberikan penguatan dengan mengemukakan kembali beberapa contoh perilaku berbaik sangka berdasarkan buku teks dan bahan ajar yang telah dikembangkan.

i. Contoh Berbaik Sangka pada Nilai-Nilai Budaya Lokal

j. Peserta didik secara berkelompok kembali mengidentifikasi dan mendiskusikan contoh-contoh perilaku berbaik sangka dengan fenomena kehidupan yang mereka alami di lingkungan sekitar. Berdasarkan hasil identifikasi tersebut, setiap kelompok merumuskan beberapa pertanyaan untuk dikemukakan pada kelompok lain.

k. Setiap kelompok menyampaikan hasil diskusinya, sementara kelompok lain ikut serta mencermati dan mengemukakan beberapa pertanyaan yang relevan yang telah dipersiapkan bersama kelompok.

l. Guru memberikan penguatan dengan mengemukakan kembali beberapa contoh perilaku berbaik sangka berdasarkan buku teks dan bahan ajar yang telah dikembangkan.

\footnotetext{
${ }^{31}$ Roli Abdul Rohman. Menjaga Akidah dan Akhlak, (Solo: PT Tiga Serangkai Pustaka Mandiri, 2009), hal. 86

32 T. Ibrahim dan Darsono. Membangun Akidah dan Akhlak 2, (Solo: PT Tiga Serangkai Pustaka Mandiri, 2009), hal. 103-113

33 Yatimin Abdullah. Studi Akhlak dalam Perspektif al-Qur'an, (Jakarta: Amzah, 2007), hal. 219-220
} 


\section{Penutup}

Pertama, upaya inovasi dalam kurikulum PAI kelas VI tingkat SD di wilayah suku tengger setidaknya dengan penambahan (addition), inovasi yang besifat penambahan dan penguatan (reinforcement) pada komptensi dasar, materi pembelajarn dan kegiatan pembelajaran.

Kedua, Upaya penambahan dan penguatan yang dimaksud pada silabus, terutama pada materi pembelajaran dan kegiatan pembelajaran kelas VI pada pelajaran satu (Indahnya Saling Menghormati), pelajaran enam (Indahnya Saling Membantu), pelajaran delapan (senangnya berakhlak terpuji), dan pelajaran sembilan (Ayo berinfak dan bersedekah).

Ketiga, setelah silabus dikembangkan, maka selanjutnya mengembangkan Rencana Pelaksanaan Pembelajaran. Proses ini merupakan bagian dari upaya meningkatkan kualitas pembelajaran langsung, dimana peserta didik mengembangkan pengetahuan, kemampuan berpikir dan keterampilan psikomotorik melalui interaksi langsung dengan sumber belajar yang dirancang dalam silabus dan RPP berupa kegiatan-kegiatan pembelajaran sesuai dengan kondisi masyarakat suku Tengger.

\section{Daftar Pustaka}

Abdullah. . Yatimin. Studi Akhlak dalam Perspektif al-Qur'an, Jakarta: Amzah, 2007. Al-Quran, Departemen Agama RI. al-Qur'an dan Terjemahnya. Juz 1 Juz 30. Jakarta: Yayasan Penyelenggara Penterjemah al-Qur'an, 1982-1983

Aplikasi MS. Quran In Word Kemenag, Lajnah Pentashih Mushaf al-Quran Kemenag. V.2.2. 2013. QS. 49:12-13.

Armiah, "Internalisasi Nilai-Nilai Keagamaan Lewat Media," Alhadharah, Vol.13, No. 25, 2014.

Beatty, Andrew. Varian Agama di Jawa: Suatu Pendekatan Antropologi, terj. Achmad Fedyani Saifuddin Jakarta: Raja Grafindo Persada, 1999.

Darsono. T. Ibrahim dan Membangun Akidah dan Akhlak 2, .Solo: PT Tiga Serangkai Pustaka Mandiri, 2009.

Data Statistik Diantaranya, SDN Tosari I, SDN Tosari II, SDN Mororejo I, dan SDN Mororejo II. Lihat http://dapo.dikdasmen.kemdikbud.go.id/sp/3/051904. diakses pada tanggal 30 Agustus 2018.

Dimyati \& Mudjiono, Belajar dan Pembelajaran, Jakarta: PT. Rineka Cipta, 2002, 268

Ermawi, Imam Santoso. Kearifan Lokal Dalam Perencanaan dan Perancangan Kota Untuk Mewujudkan Arsitektur Kota Yang Berkelanjutan Malang: Group Konservasi Arsitektur dan Kota, Universitas Merdeka Malang, 2009.

Hasbullah, "Rewang: Kearifan Lokal dalam Membangun Solidaritas dan Integrasi Sosial Masyarakat di Desa Bukit Batu Kabupaten Bengkalis, "Jurnal Sosial Budaya, Vol. 9, No. 2, 2012..

Hilmy, Masdar. "Induktivisme Sebagai Basis Pengembangan Ilmu Pengetahuan Dalam Islam", Jurnal Studi Keislaman Volume 17 Nomor 1 Juni 2013. 
Hilmy, Masdar. Islam and Javanese Acculturation: Textual and Contextual Analysis of The Slametan Ritual, Canada: McGill University Montreal, 1999.

Huberman, AM. Understanding Change in Education. New York. IBE; 1973.

Kabupaten Pasuruan Dalam Angka 2014. Badan Pusat Statistik Kabupaten Pasuruan, 213.

Kementerian Pendidikan dan Kebudayaan. Buku Guru Pendidikan Agama Islam dan Budi Pekerti. Jakarta: Kementerian Pendidikan dan Kebudayaan, 2015.

Koentjaraningrat, Sejarah Teori Antropologi I, Jakarta: UI-PRESS, 1987.

Muhaimin, Arah Baru Pengembangan Pendidikan Islam Yogyakarta: Nuansa, 2003, 183.

Nashihin, "Internalisasi Nilai-Nilai Agama Islam dalam Pembinaan Akhlak Mulia," Jurnal Ummul Qura, Vol. 5, No. 1, 2015.

Nasution, S. Sosiologi Pendidikan. Edisi 2, cetakan 4Jakarta: Bumi Aksara,2009, 148

Nursisto, Membumikan Pembelajaran Agama Islam Yogyakarta: Adi Cita Karya Nusa, 2008.

Oemar Hamalik, Pendidikan Guru: Berdasarkan Pendekatan Kompetensi, Jakarta: PT. Bumi Aksara, 2002.

Pak Jono, Ceritane Karo Ceritane Kasodo, 2005.

Rohman. Roli Abdul. Menjaga Akidah dan Akhlak, .Solo: PT Tiga Serangkai Pustaka Mandiri, 2009.

Sanjaya, Wina. Inovasi Kurikulum dan Pembelajaran: Teori dan Praktik Pengembangan Kurikulum TingkatSatuan Pendidikan KTSP, Jakarta: Kencana Prenada Media Group, 2010

Sutarto, Ayu. Sastra Lisan Tengger Pilar Utama Pemertahanan Tradisi Tengger, Jurnal ATAVISME, Volume 12, No. 1, Edisi Juni 2009

Sutarto, Ayu. Sekilas Tentang Masyarakat Suku Tengger, Makalah disampaikan pada acara pembekalan Jelajah Budaya 2006 yang diselenggarakan oleh Balai Kajian Sejarah dan Nilai Tradisional Yogyakarta, tanggal 7-10 Agustus 2006.

Yani, Turhan. Sistematika dan Relevansi Materi Ajar PAI dalam Kurikulum Berbasis Kompetensi Surabaya: Lemlit Unesa, 2007.

Four D. Model, dan model pengembangan Dick and Carey. Dick and Carey, The Systematic Design of Instruction, Florida: Harper Collens Publisher, 1990

Nana Syaodih Sukmadinata, Metode Penelitian Pendidikan, Bandung: Rosda Karya,, 2009

Salinan Peraturan Menteri Pendidikan Dan Kebudayaan Republik Indonesia Nomor 24 Tahun 2016 tentang Kompetensi Inti Dan Kompetensi Dasar Pelajaran pada Kurikulum 2013 Pada Pendidikan Dasar Dan Pendidikan Menengah 